\title{
Modes of morphogenesis inheritance in vitro in strawberry (Fragaria $x$ ananassa Duch.)
}

\author{
Magdalena Dyduch-Siemińska ${ }^{1}$ Jadwiga Żebrowska ${ }^{1}$ Jacek Gawroński ${ }^{1}$ ]
}

Received: 12 April 2018 / Accepted: 20 August 2018 / Published online: 29 August 2018

(c) The Author(s) 2018

\begin{abstract}
The phenomenon of morphogenesis observed in in vitro cultures, as the ability of cultured cells and/or plant tissues to regenerate into a complete plant, is used for propagation of orchard species plants of the genus Fragaria spp. Genetic mechanisms controlling the in vitro morphogenesis process are still not fully understood. Research has been conducted to broaden knowledge about the genetic control of this process. The aim of this study was to determine the effect of cytoplasmic loci on the inheritance of the cell morphogenetic potential within the species Fragaria $x$ ananassa. The study included five strawberry cultivars-'Dukat', 'Jota', 'Temptation', 'Pastel' and 'Senga Sengana'. The third Griffing method of diallel crossing was fully useful for achieving the purpose of the research, because it allowed, by comparing the effects of reciprocal crosses for each crossing combination, determining the possible impact of cytoplasmic loci on the inheritance of morphogenetic abilities in the analyzed cultivars. Evaluation of the effects of reciprocal crosses showed different modes of inheritance of the morphogenetic potential in vitro of plant cells of these strawberry cultivars. The strawberry cultivar 'Dukat' transmitted genetic determinants of the morphogenetic potential cytoplasmically. Nuclear transmission of the morphogenetic potential was recorded for the cultivar 'Senga Sengana'. 'Jota', 'Temptation' and 'Pastel' cultivars passed on this trait in a cytoplasmic-nuclear mode. Morphogenesis efficiency of hybrids, whose maternal forms transmitted the morphogenetic potential in a cytoplasmic-nuclear mode, depended likely on the interaction between the maternal plasmotype and the paternal nuclear genes.
\end{abstract}

Keywords Cytoplasmic inheritance $\cdot$ Diallel crossing $\cdot$ Epistatic interactions $\cdot$ Morphogenetic potential $\cdot$ Reciprocal crosses

\section{Introduction}

Increasingly more species of plants-including many of great economic importance-are propagated on a commercial scale using the tissue culture method. The bases of plant in vitro cultures are plant morphogenetic abilities (Zhuravlev and Omelko 2008; Vidal et al. 2014). The phenomenon of morphogenesis observed in in vitro cultures, as the ability of cultured cells and/or plant tissues to regenerate into a complete plant, is used for propagation of orchard species plants of the genus Fragaria spp. The totipotency exhibited by the apical meristem and adjacent portions of the shoot apex are

Communicated by Henryk Flachowsky.

Jacek Gawroński

jacek.gawronski@up.lublin.pl

1 Department of Genetics and Horticultural Plant Breeding, University of Life Sciences in Lublin, Akademicka 15, 20-950 Lublin, Poland the basis for the commercial micropropagation process of strawberry plants (Rout et al. 2000; Lisiecka 2014; Ikeuchi et al. 2016). The Fragaria $x$ ananassa species was introduced into in vitro cultivation about 40 years ago (Boxus 1974). In a short time, this reproduction method of plants of this species found many supporters, mainly among the most important European companies involved in the seedling production. The material from in vitro cultures is of excellent quality and such plants produce a greater number of runners than conventionally propagated plants shortly after planting on plantations (Boxus et al. 2000; Żebrowska et al. 2003; Mohan et al. 2005). Therefore, in vitro clonal reproduction of strawberry plants is used in breeding programs for the production of many comparable seedlings in parallel. In addition, strawberry seedlings in vitro can be kept at low temperatures for a long time, which allows to preserve the genetic resources of this species. New plant can be obtained in vitro by direct and indirect organogenesis as well as by using somatic embryogenesis (Debnath and Silva 2007). The process of morphogenesis inheritance is best known and 
described for cereals. Bhaskaran and Smith (1990) and Bregitzer and Campbell (2001) found that in vitro cereal morphogenetic abilities are inherited quantitatively. Tyankova et al. (2006) and Oleszczuk and Zimny (2000) reported that the morphogenetic potential of plant cells and tissues was a quantitative trait, and thus polygenically determined. Hence, a thorough understanding of its genetic determinants is difficult and requires observation of the phenotypic expression of the trait in numerous populations and to conduct many genetic analyses using special research methods. One of the methods of studying the inheritance of quantitative traits are different models of diallel crossings used due to the reliability of the results obtained as well as practical significance in plant breeding and biotechnology. Quantitative traits can be determined by nuclear genes or extranuclear genes, which are localized in the organelles (plastids and/or mitochondria). As a rule traits conditioned by extranuclear factors segregate during mitotic divisions, and do not show segregation during meiotic divisions, unlike nuclear genes. The main method of detecting extranuclear factors is to analyze their inheritance in further generations of heteroplasmic individuals. If hybrids resulting from reciprocal crossing between two parental forms have distinct phenotypes, it can often be an indication of extranuclear factor expressions (Gajewski 1987). Thus, using reciprocal crosses, one can detect the influence of cytoplasmic genes, because they are generally inherited only from the mother. This does not mean, however, that microspores do not contain chloroplasts and mitochondria, but it is assumed that they are eliminated during fertilization and consequently are not passed on to the zygote (Hagemann 2002; Frei et al. 2003).

Genetic mechanisms controlling the in vitro morphogenesis process that determine the regeneration of cells and tissues into a complete plant are still not fully understood. Due to the great importance of in vitro reproduction both in the cultivation and breeding of strawberries, research has been conducted to broaden knowledge about the genetic control of this process. The object of this study was to determine the possible effect of extranuclear loci on the inheritance of the cell morphogenetic potential within the species Fragaria $x$ ananassa. Previous studies have not taken into account the role of extranuclear DNA in the inheritance of this trait in species of the genus Fragaria, hence the conducted research is an attempt to fill this gap in identifying the genetic determination of in vitro morphogenesis.

\section{Materials and methods}

Genetic research on in vitro morphogenesis was performed using the octoploid species Fragaria $x$ ananassa Duch. (strawberry) containing $2 n=8 x=56$ chromosomes.
The research was carried out in 2012-2015. It included five strawberry cultivars (Fragaria x ananassa Duch.) 'Dukat', 'Jota', 'Temptation', 'Pastel' and 'Senga Sengana'. The origin of the strawberry cultivars is given in Table 1.

\section{Obtaining the hybrid material}

A crossing system according to the third Griffing method (Griffing 1956) was performed in order to obtain the hybrid offspring of the $F_{1}$ generation necessary for the experiments. The applied method consisting in performing simple and reciprocal crosses allows determining the influence of extranuclear loci on the inheritance of the examined trait by comparing the effects of reciprocal crosses for each cross combination (Ubysz-Borucka et al. 1985). The number of cross combinations using five $(\mathrm{p}=5)$ parental forms was $\mathrm{p}$ (p - 1), i.e., 20.

\section{Evaluation of the expression of morphogenetic abilities of $F_{1}$ hybrids in in vitro culture}

Evaluation of the expression of morphogenetic abilities of segregating F1 progeny populations was performed under in vitro culture conditions. Achenes of hybrid populations, i.e., the seed material, after prior surface sterilization in 5\% aqueous sodium hypochlorite solution for $2 \mathrm{~h}$ and three times rinsing in sterile distilled water, were placed in Petri dishes with medium prepared on the basis of standard MS medium according to Murashige and Skoog (1962) without growth regulators and with limited sucrose concentration $(5 \mathrm{~g} / \mathrm{L})$. The $\mathrm{pH}$ of the medium was adjusted to 5.7 and sterilized in an autoclave at $121{ }^{\circ} \mathrm{C}$ for $20 \mathrm{~min}$ at $0.1 \mathrm{MPa}$. The plates with the seeds were placed at a temperature of $+4{ }^{\circ} \mathrm{C}$ for a period of 8 weeks for stratification. After stratification, the plates were transferred to the growth chamber (photoperiod: $16 \mathrm{~h}$ day $/ 8 \mathrm{~h} \mathrm{night,} 40 \mu \mathrm{mol} / \mathrm{m}^{2} / \mathrm{s}$ ) and seed germination was observed.

The emerging seedlings (primary explants) were transferred in the cotyledon phase, 40 for each cross

Table 1 Comparison of the origin of the analyzed five strawberry cultivars

\begin{tabular}{ll}
\hline Cultivar & Origin of cultivar \\
\hline 'Dukat' & Koralowa $100 \times$ Gorella \\
'Jota' & $\left(\right.$ Tioga $\mathrm{S}_{1} \times$ Cambridge \\
& Vigour $\left.\mathrm{S}_{1}\right) \times$ Dukat \\
'Temptation' & Selection of $F \times$ ananassa \\
'Pastel' & Paula $\times 3040=$ Paula $\times$ \\
& $($ Senga Sengana $\times$ Talis- \\
& man $)$ \\
'Senga Sengana' & Markee $\times$ Sieger \\
\hline aAccording to Nat.Germplasm Repository & Corvallis
\end{tabular}

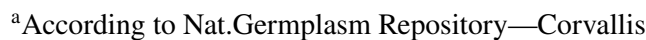


combination, to sterile MS medium with the addition of growth regulators (gibberellic acid $\mathrm{GA}_{3}-0.01 \mathrm{mg} / \mathrm{L}$, indolyl-3-acetic acid IAA-1 mg/L; 6-benzylaminopurine $\mathrm{BAP}-1 \mathrm{mg} / \mathrm{L}$ ) to induce morphogenesis. After 8 weeks, the cultures propagated from the primary explants were divided into single microshoots and their number was counted - the first stage of culture. Subsequently, one microshoot was randomly selected from each propagated explant, and it was transplanted into MS medium with the same composition for further proliferation. Each offspring combination was represented by 40 microshoots. After the next 8 weeks, the propagated cultures were divided into microshoots and counted-the second stage of culture. In total, the morphogenesis efficiency was estimated for 1600 explants in the first and second stages of culture.

\section{Biometric analysis of the hybrid material}

The $\mathrm{F}_{1}$ generation hybrids obtained from crosses were subjected to biometric analysis. The efficiency of morphogenesis in subsequent stages of the in vitro culture of each offspring combination was expressed by the average number of microshoots obtained from 40 randomly explants selected for propagation. The results were subjected to the analysis of variance for the diallel crossing model according to the third Griffing method. General (GCA) and specific (SCA) combining ability and the effects of reciprocal crosses $\left(r_{i j}\right)$ were estimated for each parental form used for crossbreeding in relation to the analyzed trait. The significance of the differences between the efficiency of the total and specific combining capacities was estimated based on the multiple Tukey confidence intervals at $\mathrm{P} \leq 0.05$, while the effects of reciprocal crosses significantly different from zero were calculated based on the Student $t$-test.

\section{Results}

High differences were found in the number of microshoots formed by explants of segregating strawberry progeny combinations in the first culture passage (Table 2). The average morphogenesis efficiency in the analyzed diallel crossing

Table 2 The average number of microshoots obtained in the first stage of culture for the $\mathrm{F}_{1}$ progeny combinations of five strawberry cultivars crossed in the diallel system according to the third Griffing method

\begin{tabular}{|c|c|c|c|c|c|c|}
\hline o & Dukat & Jota & Temptation & Pastel & $\begin{array}{c}\text { Senga } \\
\text { Sengana }\end{array}$ & Mean + . \\
\hline Dukat & & 5.67 ef $^{1}$ & $3.67 \mathrm{f}$ & 5.15 ef & 4.00 ef & $4.62 \mathrm{c}^{2}$ \\
\hline Jota & 6.07 def & & 7.97 cdef & 7.37 cdef & 6.37 cdef & $6.95 \mathrm{~b}$ \\
\hline Temptation & 9.02 cde & 4.97 ef & & 7.40 cdef & 8.90 cde & $7.57 \mathrm{~b}$ \\
\hline Pastel & $10.82 \mathrm{bcd}$ & $19.22 \mathrm{a}$ & 8.17 cdef & & 8.97 cde & 11.80 a \\
\hline $\begin{array}{c}\text { Senga } \\
\text { Sengana }\end{array}$ & 7.87 cdef & $14.62 \mathrm{ab}$ & $11.35 \mathrm{bc}$ & $15.57 \mathrm{ab}$ & & $12.36 \mathrm{a}$ \\
\hline Mean.$\widehat{\jmath}$ & $8.45 b^{3}$ & $11.12 \mathrm{a}$ & $7.79 \mathrm{~b}$ & $8.87 \mathrm{ab}$ & $7.06 \mathrm{~b}$ & 8.66 \\
\hline
\end{tabular}

Means marked with the same letter do not differ significantly at $\mathrm{P}=0.05$

${ }^{1}$ For LSD $=5.13$

${ }^{2}$ For LSD $=2.10$

${ }^{3}$ For LSD $=2.25$ 
Table 3 The average number of microshoots obtained in the second stage of culture for the $\mathrm{F}_{1}$ progeny combinations of five strawberry cultivars crossed in the diallel system according to the third Griffing method

\begin{tabular}{|c|c|c|c|c|c|c|}
\hline $0^{1}$ & Dukat & Jota & Temptation & Pastel & $\begin{array}{c}\text { Senga } \\
\text { Sengana }\end{array}$ & Mean $q$. \\
\hline Dukat & & $8.57 \operatorname{defg}^{1}$ & $5.37 \mathrm{~g}$ & 9.87 cdefg & $6.65 \mathrm{fg}$ & $7.62 \mathrm{~b}^{2}$ \\
\hline Jota & 9.35 defg & & 9.45 defg & 8.27 defg & 7.95 efg & $8.76 \mathrm{~b}$ \\
\hline Temptation & 11.22 bcdef & $6.22 \mathrm{fg}$ & & 9.22 defg & 8.45 defg & $8.78 \mathrm{~b}$ \\
\hline Pastel & $13.12 \mathrm{bcd}$ & 19.17 a & 11.32 bcdef & & 9.50 defg & $13.28 \mathrm{a}$ \\
\hline $\begin{array}{c}\text { Senga } \\
\text { Sengana }\end{array}$ & 10.35 cdefg & 15.00 abc & $15.60 \mathrm{ab}$ & 13.00 bcde & & $13.49 \mathrm{a}$ \\
\hline Mean $\cdot \widehat{ }{ }^{\lambda}$ & $11.01 a^{3}$ & $12.24 \mathrm{a}$ & 10.44 a & 10.09 ab & $8.14 \mathrm{~b}$ & 10.39 \\
\hline
\end{tabular}

Means marked with the same letter do not differ significantly at $\mathrm{P}=0.05$

${ }^{1}$ For LSD $=5.12$

${ }^{2}$ For LSD $=2.06$

${ }^{3}$ For $\mathrm{LSD}=2.16$

Table 4 Analysis of variance for morphogenesis efficiency in the progeny combinations of five strawberry cultivars crossed in the diallel system according to the third Griffing method

\begin{tabular}{lccc}
\hline $\begin{array}{l}\text { Source of } \\
\text { variation }\end{array}$ & $\begin{array}{l}\text { Degrees of } \\
\text { freedom }\end{array}$ & Sum of squares & Mean square \\
\hline GCA & 4 & 65.52 & $16.38^{*}$ \\
SCA & 5 & 26.24 & $5.248^{*}$ \\
$\mathrm{r}_{\mathrm{ij}}$ & 10 & 157.06 & $15.71^{*}$ \\
Error & 1580 & 1964.34 & 1.24 \\
\hline
\end{tabular}

GCA general combining ability, $S C A$ specific combining ability, $r_{i j}$ reciprocal cross effects

*Significantly different from zero

system was nearly nine microshoots per explant. The maximum value of the analyzed trait was 19.22 for the offspring of 'Pastel' $\times$ 'Jota' cross combinations. The smallest number of microshoots was formed by offspring explants of the combination 'Dukat' $\times$ 'Temptation' (3.67). The cultivar 'Senga Sengana', used in the diallel crossing system as a maternal form, produced offspring that was characterized by the highest average number of microshoots generated from a single explant (12.36). On the other hand, half-siblings of the 'Dukat' cultivar, used in the analyzed cross system as the maternal form, generated the lowest number of microshoots (average 4.62). The highest average number of microshoots was obtained from half-sibling explants of the paternal cultivar 'Jota' (11.12). The average values of the trait did not differ significantly between the offspring obtained using the remaining cultivars as paternal forms.

High differences in the number of microshoots formed by the explants of segregating strawberry progeny combinations were also found in the second culture stage (Table 3). An average of 10.39 microshoots per explant was obtained at this stage of culture. Similarly to the first stage, explants of offspring obtained from the 'Dukat' $x$ 'Temptation' combination produced the lowest number of microshoots in the second stage (5.37). The highest number of microshoots was obtained for the offspring of the 'Pastel' $\times$ 'Jota' combination (19.17). At this stage of culture, the average number of microshoots obtained for half-siblings, in which the 'Dukat', 'Jota' and 'Temptation' cultivars were used as maternal forms, was significantly lower than the means obtained for half-siblings of the 'Pastel' and 'Senga Sengana' cultivars. The half-sibling of the 'Senga Sengana' cultivar, used in the system as a paternal component, was characterized by 
the lowest number of microshoots. The average number of microshoots did not differ significantly between the offspring obtained using the remaining cultivars as paternal forms. The efficiency of morphogenesis varied within the progeny of the analyzed strawberry genotypes between the first and the second stage of culture. The average number of microshoots (8.33) produced by primary explants in the first culture stage was lower than the average number of explants obtained in the second stage (10.39). The analysis of the offspring obtained as a result of the conducted crosses showed that the average number of microshoots obtained in the first stage was higher than in the second stage only for three of them: 'Temptation' $x$ 'Senga Sengana', 'Pastel' $\times$ 'Jota' and 'Senga Sengana' $\times$ 'Pastel'.

Analysis of variance according to the third Griffing model (Griffing 1956) for morphogenesis efficiency showed a significant differentiation of GCA and SCA effects and the effects of reciprocal crosses for the tested parental forms and offspring of particular cross combinations (Table 4). The GCA effects played a greater role than the SCA effects in conditioning the morphogenetic abilities of the hybrid progeny.

\section{GCA analysis}

The point scores of the general combining ability (GCA) effects were shown in Table 5. The scores of GCA effects varied between the cultivars and had positive ('Jota', 'Pastel', 'Senga Sengana') as well as negative ('Dukat' and 'Temptation') values. GCA values proved to be significantly different from zero for the majority of the cultivars (apart from the cultivar 'Jota'). The cultivar 'Pastel' was characterized by the highest positive GCA value in the present system of diallel crossing. The lowest negative GCA value was estimated for the cultivar 'Dukat'. The lowest positive GCA effect recorded for the cultivar 'Jota' was insignificantly different from the 'Senga Sengana' GCA effect, but differed significantly from the 'Pastel' GCA effect.

\section{SCA analysis}

The point scores of the SCA effects were shown in Table 5 . They showed that these effects assume positive and negative values and the significance of many of them is statistically verified. The significance of any SCA effects on

Table 5 General (GCA) and specific (SCA) (above diagonal) combining ability and effects of reciprocal crosses ( $\mathrm{r}_{\mathrm{ij}}$ ) (under the diagonal) for morphogenesis efficiency in the $\mathrm{F}_{1}$ offspring of five strawberry cultivars crossed in the diallelic system according to the third Griffing method

\begin{tabular}{|c|c|c|c|c|c|c|}
\hline $0^{\lambda}$ & Dukat & Jota & Temptation & Pastel & $\begin{array}{c}\text { Senga } \\
\text { Sengana }\end{array}$ & GCA \\
\hline Dukat & & $-0.31 a b c^{n i}$ & $1.09 a b^{n i}$ & $0.36 \mathrm{abc}^{\mathrm{ni}}$ & $-1.14 b c^{*}$ & $-2.13 c^{* 2}$ \\
\hline Jota & $-0.29 a b^{n i 3}$ & & $-1.52 c^{*}$ & $1.67 a^{*}$ & $0.15 a b c^{n i}$ & $0.33 b^{n i}$ \\
\hline Temptation & $-2.8 \mathrm{~cd}^{*}$ & $1.56 \mathrm{a}^{*}$ & & $-1.30 c^{*}$ & $1.73 \mathrm{a}^{*}$ & $-1.17 c^{*}$ \\
\hline Pastel & -2.23 bcd $^{*}$ & $-5.69 \mathrm{e}^{*}$ & $-0.72 b c^{n i}$ & & $-0.72 b c^{\mathrm{ni}}$ & $1.98 \mathrm{a}^{*}$ \\
\hline $\begin{array}{c}\text { Senga } \\
\text { Sengana }\end{array}$ & -1.89 bcd $^{*}$ & $-3.82 \mathrm{de}^{*}$ & -2.40 bcd $^{*}$ & $-2.52 \mathrm{bcd}$ & & $0.98 a b^{*}$ \\
\hline
\end{tabular}

Means marked with the same letter do not differ significantly at $\mathrm{P}=0.05$

$S d$ standard deviation

*Significantly different from zero/ns—insignificantly different from zero

${ }^{1}$ For LSD $=2.38$

${ }^{2}$ For LSD $=1.39$

${ }^{3}$ For LSD $=2.24$ 
morphogenesis efficiency has not been proven in 5 combinations: 'Dukat' $\times$ 'Jota', 'Dukat' $\times$ 'Temptation', 'Dukat' $\times$ 'Pastel', 'Jota' $\times$ 'Senga Sengana' and 'Pastel' $\times$ 'Senga Sengana'. Specific parental pairs, 'Jota' $\times$ 'Pastel' and 'Temptation' $\times$ 'Senga Sengana', had significantly positive SCA effects, which amounted to 1.67 and 1.73, respectively. Parental pairs: 'Dukat' $\times$ 'Senga Sengana', 'Jota' $\times$ 'Temptation' and 'Temptation' $\times$ 'Pastel' were characterized by significantly negative SCA values.

\section{Analysis of reciprocal cross effects: $\boldsymbol{r}_{\mathrm{ij}}$}

The results of the assessment of reciprocal cross effects of five parental forms were provided in Table 5. They showed that the number of generated microshoots from the explant was higly differentiated in the majority of cross combinations. Offspring of a simple cross combinations, in which the cultivar 'Dukat' was a maternal form, had significantly fewer microshoots per explant than hybrids obtained from reciprocal crosses (of opposite directions) (Tables 2, 3). Only the cross combination between 'Dukat' and 'Jota' did not show the significant differences between the number of microshoots produced from the simple and reciprocal crosses. There were significantly negative values of the effects of reciprocal crosses in the cultivar 'Jota' used in this diallel crossing system as the maternal component in relation to two paternal forms, i.e., 'Pastel' and 'Senga Sengana'. The $r_{i j}$ effects for the cultivar 'Temptation' were negative in relation to the three paternal components: 'Jota', 'Pastel' and 'Senga Sengana'. The results obtained from crosses with the 'Pastel' paternal form were the only statistically insignificant outcomes. A high, significantly negative effect of reciprocal crosses was obtained for the cultivar 'Pastel' in a cross combination with the cultivar 'Senga Sengana'. The remaining combinations of this cultivar used as a maternal form showed positive effects. The cultivar 'Senga Sengana', used as a maternal form, showed significant positive effects of reciprocal crossing in relation to all analyzed paternal forms.

\section{Discussion}

Most of the utility plant traits are polygenically-controlled quantitative traits. Reports based on the results of many authors indicate that the morphogenetic potential of plant cells and tissues is also a quantitative and, therefore, polygenic trait (Oleszczuk and Zimny 2000; Li et al. 2003; Tyankova et al. 2006; Dodig et al. 2008). The genotype of the primary explant is the most important factor determining the effective regeneration of plants from callus in various monocotyledonous plant species (Mathias 1990; Li et al. 2003). However, still little is known about the nature of

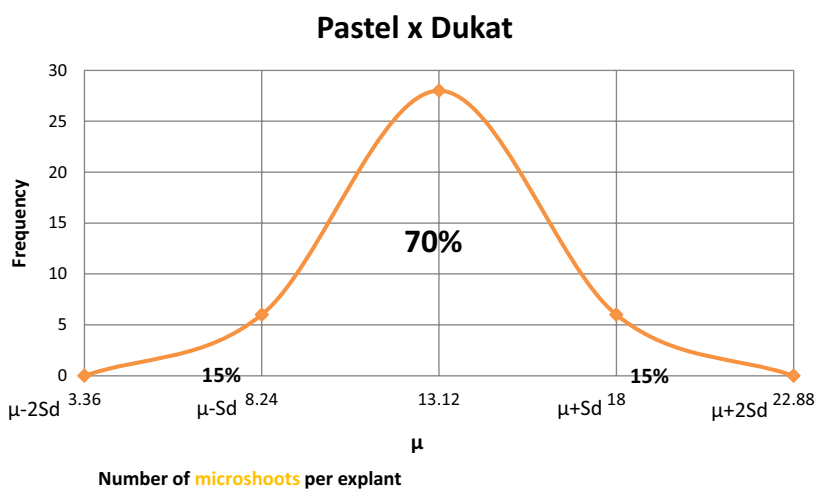

Fig. 1 The morphogenesis efficiency curve for the 'Pastel' $\times$ 'Dukat' offspring combination in the second culture stage (normal distribution curve). $S d$ standard deviation

genetic control of plant regeneration in vitro. According to Komatsuda et al. (1989) and Mano et al. (1996), regeneration of somatic embryos from callus of barley is controlled by several genes. Willman et al. (1989) suggested that maize had one gene or block of genes that control somatic morphogenesis in this species. Bregitzer and Campbell (2001) have identified quantitative trait loci for the regeneration of barley plants. The results of the research carried out in this work also confirmed the quantitative nature of morphogenetic potential inheritance of cultivars of Fragaria x anana$s s a$ species analyzed in vitro. A differentiated distribution of the results within the analyzed progeny combinations was found with simultaneous, often small differences in the morphogenesis efficiency between individual explants, which caused the variation observed for this trait to be continuous, characteristic of quantitative inheritance. This is demonstrated by the normal distribution curve of the morphogenesis efficiency for an exemplary offspring combination of 'Pastel' $\times$ 'Dukat' in the second stage of culture (Fig. 1).

Basic genetic knowledge about the cultivars (genotypes) and their traits, as well as the mode of inheritance of individual characteristics is necessary to achieve defined aims during breeding (Ukalska et al. 2007; Sieczko et al. 2008). Different diallel crossing models are used to determine the inheritance of a specific trait and identify the best parental components. In strawberry, such diallel crosses were conducted to investigate the inheritance of quantitative traits, such as fruit yield, fruit weight, susceptibility to gray mold or color and firmness of fruits (Masny et al. 2005). Such crosses were performed to study the inheritance of fruit ripening time (Żurawicz et al. 2006; Bestfleisch et al. 2013), resistance to Colletotrichum acutatum, and powdery mildew caused by Sphaerotheca macularis and Phytophthora fragariae (Melville et al. 1980; Gimenez and Ballington 2002; Davik and Honne 2005). The third Griffing method of diallel crossing was fully useful for achieving the purpose of the 
research, because it allowed, by comparing the effects of reciprocal crosses for each crossing combination, determining the possible impact of extranuclear loci on the inheritance of morphogenetic abilities in the analyzed species. Masny et al. (2010) indicated, in the study on the strawberry genome, the participation of not only the genetic material present in nuclear DNA, but also an important role of cytoplasmic inheritance in determining the quantitative traits analyzed by them. The authors point out that the comprehensive understanding of strawberry inheritance mechanisms requires a long-term and more in-depth analysis of offspring derived from crosses in a diallel system using the third Griffing method. The negative effect of reciprocal crosses $\left(r_{i j}\right)$ resulting from extranuclear (cytoplasmic) inheritance and the specific interaction of cytoplasmic maternal factors with nuclear factors (genes) of paternal forms has been observed earlier in many studies analyzing the strawberry genome (Hortyński 1987; Żurawicz 1990; Bestfleisch et al. 2013). This phenomenon was also observed in other species. The results from reciprocal crosses in wheat indicated that in addition to nuclear genes, cytoplasmic components might also have a significant impact on cell regeneration potential (Mathias et al. 1986, Ben Amer and Börner 1997). A similar phenomenon was also observed for various agrotechnical traits (Moran and Rooney 2003). Peng and Hodges (1989) presented evidence in their work that rice regeneration capacity in tissue cultures are under control of nuclear and cytoplasmic genes. It was also noted in wheat that cytoplasmic genes played an important role in the regeneration of callus plants (Lazar et al. 1984).

The results obtained in this study also showed that in vitro morphogenetic potential was inherited cytoplasmically in some strawberry cultivars. The analysis of variance of genetic parameters of hybrids revealed highly significant and differentiated effects of general and specific combining ability and the effects of reciprocal crossing for all studied traits. This showed the involvement of both additive and nonadditive variance and maternal effects in the inheritance of the morphogenetic abilities in the genus Fragaria. The ratio of the mean square values of GCA to SCA effects was 3.12 , which indicated a different contribution of additive and non-additive genes in the inheritance of morphogenetic potential in the analyzed species.

In this study there was a clear relationship between the morphogenesis efficiency and the direction of parental cultivars crossing. Thus, it was significant for the morphogenesis process, which parental component in a given cross combination was used as a maternal or paternal form. The effects of reciprocal crossing for a particular pair of parents, with negative values significantly different from zero, indicated that the cultivar used in this crossing as a maternal form transmitted the genetic material determining the morphogenetic potential of the cells cytoplasmically. The genetic interpretation of the reciprocal crossing effects showed that only the cultivar 'Senga Sengana' affected the cell morphogenetic abilities via nuclear genes. However, in the cultivar 'Dukat', these were the cytoplasmic loci that determined the morphogenetic abilities of the cells, because the effects of reciprocal crosses of this cultivar with all analyzed paternal forms were negative. The influence of mother's cytoplasm on the inheritance of morphogenetic potential was also noted in other cultivars. However, this effect was not equally strong and depended likely on the interaction between the maternal plasmotype and the genotype of hybrids. Significant negative effects of reciprocal crosses were observed in all analyzed stages of the culture for the cultivar 'Jota' used as a maternal component in relation to the two paternal components, 'Pastel' and 'Senga Sengana', which indicated the epistatic interaction of cytoplasmic loci determining morphogenesis over nuclear factors. Similarly, the $r_{i j}$ effects for the cultivar 'Temptation' were negative in relation to the three paternal components: 'Jota', 'Pastel' and 'Senga Sengana'. A high, significantly negative effect of reciprocal crosses was also obtained for the cultivar 'Pastel' in a cross combination with the cultivar 'Senga Sengana'. In other cases of crossing of these cultivars, the genotype of hybrids (nuclear loci) showed epistatic effects over the maternal cytoplasm, hence the effects of their reciprocal crosses were positive. Such diversified effects of reciprocal crosses suggested that the morphogenetic potential of these cultivars was determined by various inheritance modes, and ultimately depended on the interaction between the plasmotype of the maternal cultivar and the genotype of the nucleus of the hybrid cells. Ultimately, the morphogenetic potential and morphogenesis efficiency of cultivars, for which both negative and positive effects of reciprocal crosses with various paternal forms were found, were probably caused by the interaction of the maternal plasmotype with the nuclear genes paternal form. Where the maternal cytoplasmic loci showed the epistatic effect on the paternal nuclear genes, this resulted in lower morphogenesis efficiency in the progeny of simple crosses and parallel negative effects of reciprocal crosses. The effects of reciprocal crosses were positive in different interactions, in which the nuclear loci transmitting the morphogenetic potential showed an epistatic effect on the maternal cytoplasm.

In summary, it can be concluded that the in vitro morphogenetic potential in the analyzed strawberry cultivars was inherited via nuclear genes, cytoplasmically and a combination of these two. The effects of cytoplasmic loci over nuclear determinants appeared only in the offspring with certain paternal cultivars in the case of cytoplasmic-nuclear inheritance. When selecting other paternal forms for a given maternal cultivar, morphogenesis efficiency was determined by the nuclear loci that masked phenotypic effects of cytoplasmic loci by acting epistatically towards them. Thus, the interaction between cytoplasmic and nuclear loci in the 
mixed cytoplasmic-nuclear inheritance of morphogenetic potential in vitro in the analyzed species of the genus Fragaria depended on the selection of parental components for crossing. Therefore, this mode of inheritance of morphogenetic abilities shows some analogy to the cytoplasmicnuclear male sterility (CMS) of certain cultivated species. The CMS phenomenon is caused by mutual interactions between genes located in the cell nucleus and those located in the cytoplasm (Sofi et al. 2007; Saxena et al. 2010).

\section{Conclusions}

1. The results of the study confirmed the quantitative nature of the inheritance of morphogenetic abilities in vitro in plants of the species Fragaria x ananassa.

2. Differences in the morphogenesis ability determined by the number of microshoots produced by the explants of offspring combinations of diallel crossing systems of strawberry cultivars were significant and depended on the crossed genotypes.

3. Evaluation of the effects of reciprocal crosses showed different modes of inheritance of the morphogenetic potential in vitro of plant cells of strawberry cultivars. The strawberry cultivar 'Dukat' transmitted genetic determinants of the morphogenetic potential cytoplasmically. Nuclear transmission of the morphogenetic potential was recorded for the cultivar 'Senga Sengana'. 'Jota', 'Temptation' and 'Pastel' cultivars passed on this trait in a cytoplasmic-nuclear mode.

4. Morphogenesis efficiency of hybrids, whose maternal forms transmitted the morphogenetic potential in a cytoplasmic-nuclear mode, depended likely on the interaction between the maternal plasmotype and the paternal nuclear genes.

Author contributions MDS was responsible for conducting experiments, collecting references and writing articles, JŻ assisted to write the manuscript, JG guided and modified the whole manuscript as the corresponding author.

Open Access This article is distributed under the terms of the Creative Commons Attribution 4.0 International License (http://creativeco mmons.org/licenses/by/4.0/), which permits unrestricted use, distribution, and reproduction in any medium, provided you give appropriate credit to the original author(s) and the source, provide a link to the Creative Commons license, and indicate if changes were made.

\section{References}

Ben Amer IM, BÓ§rner A (1997) Effect of cytoplasm on immature embryo culture in wheat (Triticum aestivum $\mathrm{L}$ ). Cereal Res Commun 25:135-140
Bestfleisch M, MÓ§hring J, Hanke MV, Peil A, Flachowsky H (2013) A diallel crossing approach aimed on selection for ripening time and yield in breeding of new strawberry (Fragaria $\times$ ananassa Duch.) cultivars. Plant Breeding 133:115-120

Bhaskaran S, Smith RH (1990) Regeneration in cereal tissue culture: a review. Crop Sci 30:1328-1336

Boxus P (1974) The production of strawberry plants by in vitro micropropagation. J Horticult Sci 49:209-210

Boxus P, Jemmali A, Terzi JM, Arezki O (2000) Drift in genetic stability in micropropagation: the case of strawberry. Acta Hort 530:155-162

Bregitzer P, Campbell RD (2001) Genetic markers associated with green and albino plant regeneration from embryogenic barley. Crop Sci 41:171-179

Davik J, Honne BI (2005) Genetic variance and breeding values for resistance to a wind-borne disease [Sphaerotheca macularis (Wallr. ex Fr.)] in strawberry (Fragaria $\times$ ananassa Duch.) estimated by exploring mixed and spatial models and pedigree information. Theor Appl Genet 111:256-264

Debnath JA, Silva T (2007) Strawberry culture in vitro: applications in genetic transformation and biotechnology. Fruit Veg Cereal Sci Biotechnol 1:1-12

Dodig D, Zorić M, Mitić N, Nikolić R, Surlan-Momirović G (2008) Tissue culture and agronomic traits relationship in wheat. Plant Cell Tissue Organ Cult 95:107-114

Frei U, Peiretti EG, Wenzel G (2003) Significance of cytoplasmic DNA in plant breeding W. In Janick J ed. Plant breeding reviews, Wiley, Hoboken

Gajewski W (1987) General and molecular genetics. Polish Scientific Publishers, Warsaw 1987

Gimenez G, Ballington JR (2002) Inheritance of resistance to Colletotrichum acutatum Simmonds on runners of garden strawberry and its backcrosses. HortScience 37:686-690

Griffing B (1956) A generalised treatment of the use of diallel crosses in quantitative inheritance. Heredity 10:31-50

Hagemann R (2002) Milestones in plastid genetics of higher plants. Prog Bot 63:5-51

Hortyński J (1987) Inheritance of some quantitative traits (Fragaria $\times$ ananassa Duch.). Methods and problems of estimations. Habilitation dissertation. University of Life Sciences in Lublin

Ikeuchi M, Ogawa Y, Iwase A, Sugimoto K (2016) Plant regeneration: cellular origins and molecular mechanisms. Development 143:1442-1451. https://doi.org/10.1242/dev.134668

Komatsuda S, Enomoto K, Nakjima W (1989) Genetics of callus proliferation and shoot differentiation in barley. J Hered 80:345-350

Lazar MD, Baenziger PS, Schaeffer GW (1984) Combining abilities and heritability of callus formation and plantlet regeneration in wheat (Triticum aestivum L.) anther cultures. Theor Appl Genet 68:131-134

Li W, Ding CH, Hu Z, Lu W, Guo GQ (2003) Relationship between tissue culture and agronomic traits of spring wheat. Plant Sci 164:1079-1085

Lisiecka J (2014) Swieże, frigo czy z doniczki? Truskawka, malina, jagody 8:13-15

Mano Y, Takahashi H, Sato K, Takeda K (1996) Mapping genes for callus growth and shoot regeneration in barley (Hordeum vulgare L.). Breed Sci 57:59-70

Masny A, Madry W, Żurawicz E (2005) Combining ability analysis of fruit yield and fruit quality in ever-bearing strawberry cultivars using an incomplete diallel cross design. J Fruit Ornam Plant Res 13:5-17

Masny A, Sieczko L, Żurawicz E, Mądry W (2010) Zmienność i współzależność cech ilościowych u rodzin mieszańcowych truskawki powtarzającej owocowanie. Część II. Jedno- i wielowymiarowa analiza zmienności i grupowania. Zesz Probl Post Nauk Rol 555:561-577 
Mathias RJ (1990) Factors affecting the establishment of callus culture in wheat. In: Bajaj YPS (Ed.), Biotechnology in agriculture and forestry. Springer, New York

Mathias RJ, Fukui K, Law CN (1986) Cytoplasmatic effects on the tissue culture response of wheat (Triticum aestivum) callus. Theor Appl Genet 72:70-75

Melville AH, Draper AD, Galletta GJ (1980) Transmission of red stele resistance by inbred strawberry selections. J Am Soc Hortic Sci 105:608-610

Mohan R, Chui EA, Biasi LA, Soccol CR (2005) Alternative in vitro propagation: use of sugarcane bagasse as a low cost support material during rooting stage of strawberry cv. Dover Braz Arch Biol Technol 48:37-42

Moran JL, Rooney WL (2003) Effect on cytoplasm on agronomic performance of grain sorghum hybrids. Crop Sci 43:777-781

Murashige T, Skoog F (1962) A revised medium for rapid growth and bioassays with tobacco tissue cultures. Physiol Plant 15:473-497

Oleszczuk S, Zimny J (2000) Mikrospory zbóż w kulturach in vitro. Biotechnologia 2:142-161

Peng J, Hodges TK (1989) Genetic analysis of plant regeneration in rice (Oryza sativa L.). In Vitro Cell Dev Biol 25:91-94

Rout GR, Samantaray S, Das P (2000) In vitro manipulation and propagation of medicinal plants. Biotechnol Adv 18:91-120

Saxena KB, Sultana R, Mallikarjuna N, Saxena RK, Kumar RV, Sawargaonkar SL, Varshney RK (2010) Male-sterility systems in pigeonpea and their role in enhancing yield. Plant Breed 129:125-134

Sieczko L, Masny A, Mądry W, Żurawicz E (2008) Związki między plonem owoców oraz cechami jego jakości u truskawki powtarzającej owocowanie. Biuletyn IHAR 250:297-307

Sofi PA, Rather AG, Wani SA (2007) Genetic and molecular basis of cytoplasmic male sterility in maize. Commun Biom Crop Sc 2:49-60
Tyankova N, Zagorska D, Chardakov N, Dryanova V, Dimitrov A B (2006) Chromosomal effects on in vitro morphogenesis in wheat intervarietal substitution lines. Czech J Genet Plant Breed 42(1):15-19

Ubysz-Borucka L, Mądry W, Muszyński S (1985) The basics of stastical genetics of quantitative traits in plant breeding. Wyd. SGGWAR, Warszawa

Ukalska J, Mądry W, Ukalski K, Masny A (2007) Wielowymiarowa ocena różnorodności fenotypowej w kolekcji zasobów genowych truskawki (Fragaria $\times$ ananassa Duch.) I. Analiza zmienności. Zesz. Probl. Post. Nauk Rol. 517 (cz.II): 749-758

Vidal ÁM, Costa MAPDC, Souza ADS, Almeida WABD, Souza FVD (2014) In vitro regeneration and morphogenesis of somatic embryos of cassava. Revista Ciência Agronômica 45:558-565. https://doi.org/10.1590/S1806-66902014000300017

Willman MR, Schroll SM, Hodges TJ (1989) Inheritance of somatic embryogenesis and plantlet regeneration from primary (Type I) callus in maize. In Vitro Cell Dev Biol 25:95-100

Żebrowska JI, Czernaś J, Gawroński J, Hortyński JA (2003) Suitability of strawberry (Fragaria $\times$ ananassa Duch.) microplants to the field cultivation. Food Agric Environ 1:190-193

Zhuravlev Yu N, Omelko AM (2008) Plant morphogenesis in vitro Russian. J Plant Physiol 55(5):579-596

Żurawicz E (1990) Combining ability of varieties and clones evaluated on the basis of incomplete diallelicznego. Habilitation dissertation. Institute of Horticulture and Floriculture in Skierniewice

Żurawicz E, Masny A, Mądry W (2006) Usefulness of selected strawberry (Fragaria $\times$ ananassa) genotypes for breeding late ripening cultivars. Acta Hortic 708:501-507. https://doi.org/10.17660 /ActaHortic.2006.708.88 